Article

\title{
Zinc-modified Pt/SAPO-11 for improving the isomerization selectivity to dibranched alkanes
}

\author{
Zhichao Yang, Yunqi Liu*, Jinchong Zhao, Jianxia Gou, Kaian Sun, Chenguang Liu \\ State Key Laboratory of Heavy Oil Processing, Key Laboratory of Catalysis, China National Petroleum Corp. (CNPC), China University of Petroleum (East \\ China), Qingdao 266580, Shandong, China
}

\section{A R T I C L E I N F}

Article history:

Received 26 October 2016

Accepted 21 November 2016

Published 5 March 2017

\section{Keywords:}

Pt/SAPO-11 catalyst

Zinc

n-Octane

Hydroisomerization

Dibranched alkanes

\begin{abstract}
A B S T R A C T
Zinc-modified Pt/SAPO-11 catalysts were prepared by incipient wetness impregnation and assessed in the hydroisomerization of $n$-octane. Their physicochemical properties were investigated using powder X-ray diffraction, scanning electron microscopy, nitrogen adsorption-desorption, pyridine-adsorbed infrared spectroscopy, temperature-programmed desorption of $\mathrm{NH}_{3}$, temperature-programmed reduction of hydrogen, temperature-programmed desorption of hydrogen, transmission electron microscopy, and X-ray photoelectron spectroscopy. The addition of zinc resulted in high dispersion of platinum. Zinc acted as a competitive adsorbent, changed the location of platinum. The catalyst with a zinc loading of $0.5 \%$ gave the highest selectivity to dimethylhexanes, but the conversion was lower than those achieved with the other catalysts. Dimethylhexanes have large molecular diameters, and therefore their diffusion may be difficult. This weakens the catalytic activity of the zinc-modified catalysts and lowers the $n$-octane conversion.
\end{abstract}

(C) 2017, Dalian Institute of Chemical Physics, Chinese Academy of Sciences. Published by Elsevier B.V. All rights reserved.

\section{Introduction}

Hydroisomerization of $n$-alkanes is a valuable reaction, and it is used in industry to improve the octane number of gasoline and upgrade the cold-flow properties of diesel and lubricating oil [1-4]. The rapid expansion of the automobile industry has resulted in continuing growth in the demand for high-octane gasoline. However, the presence of $\mathrm{C}_{5}-\mathrm{C}_{8} n$-alkanes with low octane numbers decreases the quality of gasoline [5]. Therefore, many scientists devoted themselves to developing effective catalysts for converting $n$-alkanes to the corresponding branched isomers, especially multi-branched isomers [2,6-10]. Hydroisomerization catalysts contain both a metal site and an acid site, which play important roles in hydrogenation/dehydrogenation and skeletal isomerization, respectively $[11,12]$. Classical hydroisomerization proceeds over bifunctional cata- lysts via a carbenium ion mechanism $[13,14]$ : alkanes undergo dehydrogenation at metal sites and generate alkene intermediates, which are protonated at Brönsted acid sites to form alkylcarbenium ions, which undergo rearrangement. Finally, isoalkanes are formed by hydrogenation at the metal sites. The metal sources used in hydroisomerization include noble metals (platinum or palladium) [4,15-17], nickel $[18,19]$, and nickel phosphides [20]. The acid sites are usually provided by zeolites. Pt/SAPO-11 can be used for hydroisomerization because it has an appropriate metal activity, moderate acidity, and a suitable pore structure $[7,15,21]$. The catalytic activity and isomer selectivity in hydroisomerization reactions have been improved by modifying the metal component with a second metal [22-25]. Jao et al. [26] studied the effect of adding Ni to a $\mathrm{Pt} /$ mordenite catalyst. The formation rate of branched isomers increased when a moderate amount of Ni was added. Based on

\footnotetext{
* Corresponding author. Tel.: +86-532-86981861; Fax: +86-532-86981787; E-mail: liuyq@upc.edu.cn This work was supported by the National Natural Science Foundation of China (21676300). DOI: 10.1016/S1872-2067(17)62755-4 | http://www.sciencedirect.com/science/journal/18722067 | Chin. J. Catal., Vol. 38, No. 3, March 2017
} 
their experimental results, they suggested that a Ni-Pt bimetallic interaction occurred on the Ni-Pt catalyst. Yoshioka et al. [27] prepared Ni-Pt/HUSY catalysts and assessed them in $n$-hexane isomerization. They suggested that the presence of $\mathrm{Pt}$ promoted reduction of the Ni-containing catalyst. The Ni-Pt catalysts showed less deactivation and much higher activities than did Ni catalysts. Liu et al. [28] reported that modification of Pt/SAPO-11 with rare earths increased platinum dispersion and increased the catalytic activity and isomer yields. In our previous work, we investigated Sn-modified Pt/SAPO-11 catalysts in the isomerization of $n$-dodecane. We found that the isomer selectivities of Sn-modified catalysts were higher than that of Pt/SAPO-11 [29]. Saberi et al. [30-32] reported that zinc-modified Pt/HY catalysts had high selectivities for mono-branched heptane at low reaction temperatures $\left(210-255^{\circ} \mathrm{C}\right)$ and high zinc loadings $2.0 \%-16.5 \%$. They proposed the concept of a triangular site configuration to explain the role of zinc. However, there have been few reports of the use of modified Pt/SAPO-11 catalysts with zinc loadings less than $1 \%$ at high reaction temperatures (above $300^{\circ} \mathrm{C}$ ).

In the present work, we prepared a series of zinc-modified Pt/SAPO-11 catalysts and assessed them in the hydroisomerization of $n$-octane. For comparison, an unmodified Pt/SAPO-11 catalyst was prepared and assessed. The catalyst with a zinc loading of $0.5 \%$ gave the maximum isomerization selectivity to dimethylhexanes (DMHs). The effects of zinc on the active metal sites, acid sites, and isooctane selectivity are discussed.

\section{Experimental}

\subsection{Synthesis of SAPO-11}

SAPO-11 was synthesized hydrothermally as follows. Pseudoboehmite (72.8 wt $\% \mathrm{Al}_{2} \mathrm{O}_{3}$, Yantai Henghui Chemical Co., Ltd.; $13.35 \mathrm{~g}$ ) was added to deionized water (49.25 g) under stirring. Phosphoric acid (85 wt\%, Sinopharm Chemical Reagent Co., Ltd.; $21.97 \mathrm{~g}$ ) diluted with deionized water (21.11 g) was added dropwise, and the mixture was stirred for $4 \mathrm{~h}$. Di- $n$-propylamine (DPA; $98 \mathrm{wt} \%$, Sinopharm Chemical Reagent Co., Ltd.; $11.58 \mathrm{~g}$ ) was slowly added and stirring was continued for $2 \mathrm{~h}$. A silica sol (30 wt\% $\mathrm{SiO}_{2}$, Qingdao Haiyang Chemical Co., Ltd.; 5.73 g) was added to the mixture and stirring was continued for $2 \mathrm{~h}$. The molar ratios of the components in the resulting gel were $1.0 \mathrm{Al}_{2} \mathrm{O}_{3}: 1.0 \mathrm{P}_{2} \mathrm{O}_{5}: 0.3 \mathrm{SiO}_{2}: 1.2$ DPA:45 $\mathrm{H}_{2} \mathrm{O}$. The gel was placed in a Teflon-lined stainless-steel autoclave equipped with a magnetic stirrer, and crystallized at $200{ }^{\circ} \mathrm{C}$ for $24 \mathrm{~h}$ in dynamic mode. The product was separated by centrifugation and washed with deionized water to neutral $\mathrm{pH}$, dried at $120{ }^{\circ} \mathrm{C}$ for $12 \mathrm{~h}$, and calcined in air at $600{ }^{\circ} \mathrm{C}$ for $6 \mathrm{~h}$ to remove the template.

\subsection{Catalyst preparation}

The calcined SAPO-11 powder was molded using a tablet press, and crushed to 20-40 mesh. The Pt/SAPO-11 catalyst was prepared by incipient wetness impregnation with $\mathrm{H}_{2} \mathrm{PtCl}_{6}$ (AR, Sinopharm Chemical Reagent Co., Ltd.) solution. The cata- lyst was dried at $120^{\circ} \mathrm{C}$ for $2 \mathrm{~h}$ and calcined in air at $400{ }^{\circ} \mathrm{C}$ for $4 \mathrm{~h}$. The final catalyst contained $0.5 \mathrm{wt} \%$ platinum. Zinc-modified Pt/SAPO-11 catalysts were prepared analogously, except that the impregnation liquid was a mixture of $\mathrm{Zn}\left(\mathrm{NO}_{3}\right)_{2}$ (AR, Sinopharm Chemical Reagent Co., Ltd.) and $\mathrm{H}_{2} \mathrm{PtCl}_{6}$ solutions. The obtained catalysts were denoted by PtxZn/SAPO-11, where $x$ is the $\mathrm{Zn}$ loading.

\subsection{Characterization}

Powder X-ray diffraction (XRD) patterns of the samples were obtained using an X'Pert PRO MPD diffractometer (PANalytical B.V., The Netherlands) with $\mathrm{Cu} K_{\alpha}$ radiation $(\lambda=$ $0.15406 \mathrm{~nm}$ ), operated at $40 \mathrm{kV}$ and $40 \mathrm{~mA}$. Data were collected in the $2 \theta$ range $5^{\circ}-60^{\circ}$ at a scanning speed of $10^{\circ} / \mathrm{min}$.

Scanning electron microscopy (SEM) images of the sample were obtained using an S-4800 instrument (Hitachi, Japan) operated at $5 \mathrm{kV}$. Before the observations, the samples were sputtered with metal to reduce charging effects.

Nitrogen adsorption-desorption measurements were performed using an ASAP 2020 instrument (Micromeritics, USA) at $-196^{\circ} \mathrm{C}$. Prior to the measurements, all samples were degassed at $350^{\circ} \mathrm{C}$ for $3 \mathrm{~h}$ under vacuum.

Pyridine-adsorbed infrared (Py-IR) spectra were recorded using a VERTEX 70 instrument (Bruker, Germany). Prior to analysis, the samples were placed in an in situ IR cell, degassed at $400{ }^{\circ} \mathrm{C}$ for $2 \mathrm{~h}$, and cooled to room temperature. Pyridine was introduced into the cell under vacuum, and weakly adsorbed pyridine molecules were removed at $120{ }^{\circ} \mathrm{C}$ for $2 \mathrm{~h}$. The IR spectra were recorded at a resolution of $4 \mathrm{~cm}^{-1}$ and 64 scans were performed.

Temperature-programmed desorption of $\mathrm{NH}_{3}$ ( $\mathrm{NH}_{3}$-TPD) was performed using an AutoChem $2950 \mathrm{HP}$ instrument (Micromeritics, USA). The dried samples $(0.1 \mathrm{~g})$ were placed in a quartz reactor and pretreated at $600{ }^{\circ} \mathrm{C}$ in a helium flow for $2 \mathrm{~h}$. The temperature was deceased to $100{ }^{\circ} \mathrm{C}$, and then $10 \mathrm{vol} \%$ $\mathrm{NH}_{3}$ in helium was introduced at a flow rate of $50 \mathrm{~cm}^{3} / \mathrm{min}$ for $1 \mathrm{~h}$. After $\mathrm{NH}_{3}$ adsorption, the samples were purged with a helium flow for $1 \mathrm{~h}$ to remove physically adsorbed $\mathrm{NH}_{3}$. Desorption of $\mathrm{NH}_{3}$ was performed in the range $100-700{ }^{\circ} \mathrm{C}$ under a helium flow at a heating rate of $10^{\circ} \mathrm{C} / \mathrm{min}$.

Temperature-programmed reduction with $\mathrm{H}_{2}\left(\mathrm{H}_{2}\right.$-TPR) was performed using a ChemBET 3000 Chemisorption Analyzer (Quantachrome, USA). The dried samples ( $0.2 \mathrm{~g}$ ) were placed in a quartz reactor. The samples were heated from 50 to $800{ }^{\circ} \mathrm{C}$ at a heating rate of $10{ }^{\circ} \mathrm{C} / \mathrm{min}$ under a flow of $10 \mathrm{vol} \% \mathrm{H}_{2}$ in argon.

Temperature-programmed desorption of $\mathrm{H}_{2}\left(\mathrm{H}_{2}-\mathrm{TPD}\right)$ was performed using the same instrument as for $\mathrm{NH}_{3}$-TPD. The dried samples $(0.2 \mathrm{~g})$ were reduced at $450{ }^{\circ} \mathrm{C}$ in a flow of 10 vol\% $\mathrm{H}_{2}$ in argon for $2 \mathrm{~h}$, and then $\mathrm{H}_{2}$ was adsorbed on the samples at $50{ }^{\circ} \mathrm{C}$ for $1 \mathrm{~h}$. The adsorbed $\mathrm{H}_{2}$ was desorbed in the range $50-650{ }^{\circ} \mathrm{C}$ under an argon flow at a heating rate of 10 ${ }^{\circ} \mathrm{C} / \mathrm{min}$.

Transmission electron microscopy (TEM) images of the samples were obtained using a JEM-2100 UHR microscope (JEOL, Japan) operated at $100 \mathrm{kV}$. The average platinum parti- 
cle sizes $\left(d_{\mathrm{Pt}}\right)$ of the reduced samples were calculated using Gatan DigitalMicrograph software.

The amount of dispersed Pt on the catalysts was determined by $\mathrm{H}_{2}-\mathrm{O}_{2}$ titration performed using the same instrument as for $\mathrm{NH}_{3}$-TPD. The dried catalysts $(0.2 \mathrm{~g})$ were placed in a quartz reactor, and $\mathrm{H}_{2}$ (or $\mathrm{O}_{2}$ ) was injected into the quartz reactor through a six-port valve with a sample loop. The amount of dispersed Pt was calculated by assuming that each exposed Pt atom chemisorbs one hydrogen atom.

X-ray photoelectron spectroscopy (XPS) was performed using a K-Alpha instrument (Thermo Scientific, USA) equipped with an $\mathrm{Al} K_{\alpha} \mathrm{X}$-ray source. Before the spectrum was recorded, the sample was reduced at $450{ }^{\circ} \mathrm{C}$ in a flow of $10 \mathrm{vol} \% \mathrm{H}_{2}$ in argon for $2 \mathrm{~h}$. The obtained spectrum was fitted using Gaussian and Lorentzian methods after Shirley background subtraction.

\subsection{Assessment of catalysts}

Hydroisomerization of $n$-octane (AR, Sinopharm Chemical Reagent Co., Ltd.) was performed in a fixed-bed microreactor. The reaction parameters were $280-380{ }^{\circ} \mathrm{C}, 2.0 \mathrm{MPa}, \mathrm{H}_{2} /$ $n$-octane $(\mathrm{V} / \mathrm{V})$ ratio 400 , and various weight hourly space velocities. Before assessment, the catalysts were pretreated in an $\mathrm{H}_{2}$ flow at $450{ }^{\circ} \mathrm{C}$ for $2 \mathrm{~h}$ and cooled to the reaction temperature. The feed was then injected into the reactor using a metering pump. After the reaction conditions were stable, the products were obtained by condensation and analyzed using an Agilent 7890A gas chromatograph equipped with a flame ionization detector and an HP-PONA capillary column (50 $\mathrm{m} \times 0.2$ $\mathrm{mm})$.

\section{Results and discussion}

\subsection{XRD and SEM results}

The XRD patterns of the samples are shown in Fig. 1. The XRD pattern of the calcined molecular sieve shows the typical

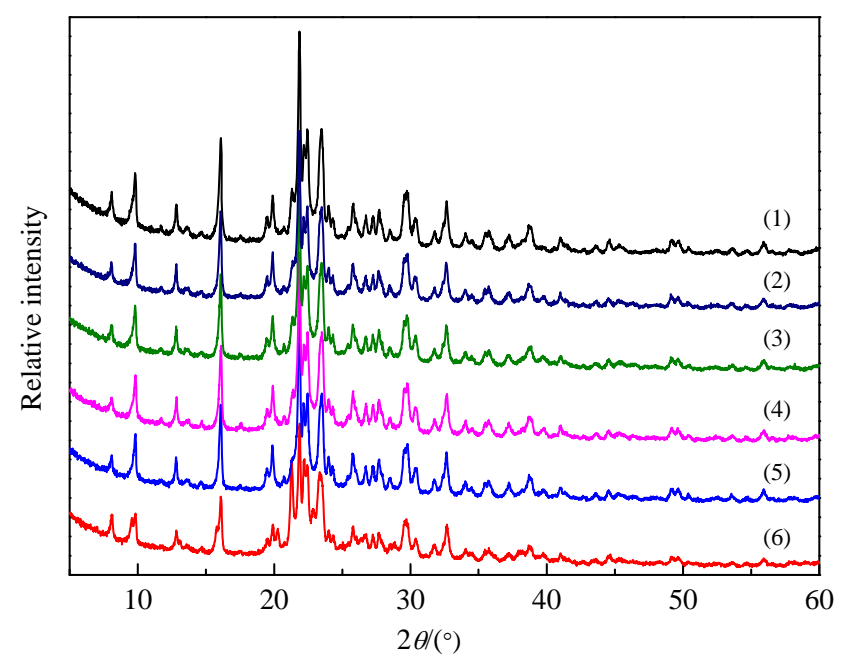

Fig. 1. XRD patterns of calcined molecular sieve and catalysts. (1) SAPO-11; (2) Pt0.7Zn/SAPO-11; (3) Pt0.5Zn/SAPO-11; (4) Pt0.3Zn/ SAPO-11; (5) Pt0.1Zn/SAPO-11; (6) Pt/SAPO-11.

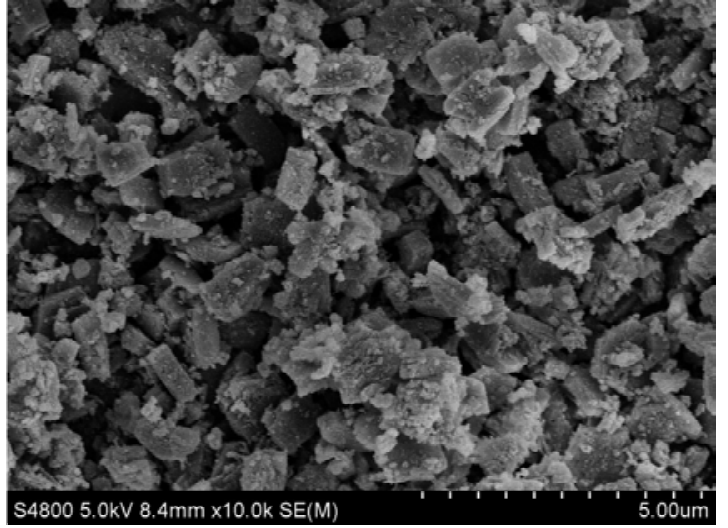

Fig. 2. SEM image of calcined SAPO-11 synthesized using dynamic hydrothermal method.

AEL structure $\left(2 \theta=8.1^{\circ}, 9.8^{\circ}, 12.8^{\circ}, 16.1^{\circ}, 20.0^{\circ}, 21.9^{\circ}\right.$, and $22.3^{\circ}-23.5^{\circ}$; PDF 047-0614). No additional peaks were detected, suggesting that the sample is free from impurities. The positions and intensities hardly changed after impregnation of the SAPO-11 support with the metal component solution, indicating that the support structure was retained. No peaks attributable to metal oxide were observed, indicating that the particles of platinum or zinc oxides were too small to be detected using XRD.

The SEM image in Fig. 2 shows that SAPO-11 had cubic crystals of approximate size $600-800 \mathrm{~nm}$. The sample did not contain spherical aggregates, which are often observed in SAPO-11 synthesized using common methods [17,21,33]. SAPO-11 is usually synthesized in static mode, which favors crystal aggregation. We synthesized SAPO-11 in dynamic mode and crystal aggregation was restrained by stirring.

\section{2. $\quad N_{2}$ adsorption-desorption and acidic properties}

Table 1 shows the pore structures and acidic properties of the samples. SAPO-11 had the largest Brunauer-Emmett-Teller (BET) surface area $\left(148 \mathrm{~m}^{2} / \mathrm{g}\right)$ and pore volume $\left(0.24 \mathrm{~m}^{3} / \mathrm{g}\right)$. The BET surface areas and pore volumes of the catalysts decreased slightly with increasing metal loading, indicating that the pores of SAPO-11 were not completely blocked by the supported platinum or zinc. Lee et al. [12] suggested that the platinum in catalysts prepared by incipient wetness impregnation is located on the external surface, whereas for catalysts prepared by ion exchange more platinum is located in the internal pores. The microporous volumes of all the catalysts were therefore almost constant and the platinum was mainly located on the external surface of the support.

The Py-IR spectra of the samples are shown in Fig. 3. All the samples gave broad vibrational bands at ca. 1455 and 1545 $\mathrm{cm}^{-1}$, from pyridine molecules adsorbed on Lewis (L) and Brönsted (B) acid sites, respectively [6]. The band at ca. 1490 $\mathrm{cm}^{-1}$ corresponds to pyridine molecules adsorbed on both $\mathrm{L}$ and B acid sites [34]. The absorbance peaks for pyridine molecules adsorbed on the L or B acid sites hardly changed after the introduction of platinum and zinc, indicating that the acid sites were only slightly affected by the metal component. The 
Table 1

Properties of SAPO-11 and catalysts.

\begin{tabular}{|c|c|c|c|c|c|c|c|c|c|}
\hline \multirow{2}{*}{ Sample } & \multirow{2}{*}{$S_{\text {BET }}\left(\mathrm{m}^{2} / \mathrm{g}\right)$} & \multirow{2}{*}{$V_{\text {micro }}\left(\mathrm{m}^{3} / \mathrm{g}\right)$} & \multirow{2}{*}{$V_{\text {meso }}\left(\mathrm{m}^{3} / \mathrm{g}\right)$} & \multirow{2}{*}{$V_{\text {total }}\left(\mathrm{m}^{3} / \mathrm{g}\right)$} & \multicolumn{3}{|c|}{ Acidity $(\mu \mathrm{mol} / \mathrm{g})$} & \multirow{2}{*}{$d_{\mathrm{Pt}}(\mathrm{nm})$} & \multirow{2}{*}{$\mathrm{H} / \mathrm{Pt}(\%)$} \\
\hline & & & & & Weak & Medium & Total & & \\
\hline SAPO-11 & 148 & 0.04 & 0.20 & 0.24 & 50.2 & 187.0 & 237.2 & - & - \\
\hline Pt/SAPO-11 & 137 & 0.04 & 0.20 & 0.24 & 74.2 & 165.2 & 239.4 & 2.54 & 39.0 \\
\hline Pt0.1Zn/SAPO-11 & 126 & 0.05 & 0.17 & 0.22 & 50.2 & 208.1 & 258.3 & 2.46 & 46.5 \\
\hline Pt0.3Zn/SAPO-11 & 125 & 0.04 & 0.16 & 0.20 & 52.3 & 204.2 & 256.5 & 2.34 & 56.8 \\
\hline Pt0.5Zn/SAPO-11 & 117 & 0.04 & 0.13 & 0.17 & 59.2 & 181.5 & 240.7 & 2.40 & 55.4 \\
\hline Pt0.7Zn/SAPO-11 & 112 & 0.04 & 0.12 & 0.16 & 50.0 & 168.4 & 218.4 & 2.36 & 51.2 \\
\hline
\end{tabular}

$\mathrm{NH}_{3}$-TPD profiles of all the samples are shown in Fig. 4. All the samples showed similar acid distributions in the $\mathrm{NH}_{3}$ desorption temperature range from 100 to $700{ }^{\circ} \mathrm{C}$, indicating that the acid distribution was not significantly affected by metal loading [35]. SAPO- 11 and the catalysts gave two $\mathrm{NH}_{3}$ desorption peaks centered at around 190 and $290^{\circ} \mathrm{C}$, corresponding to weak and medium acid sites, respectively [36]. The acidic properties of the samples were compared by separating the $\mathrm{NH}_{3}$-TPD curves into two peaks by fitting curves with Gaussian functions (a typ-

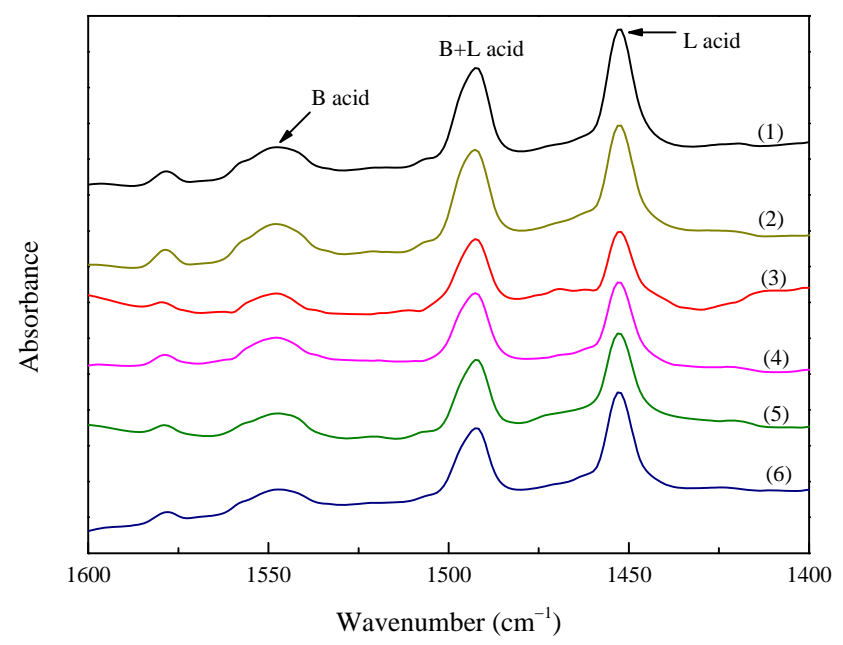

Fig. 3. Infrared spectra of pyridine adsorbed on the samples. (1) SAPO-11; (2) Pt/SAPO-11; (3) Pt0.1Zn/SAPO-11; (4) Pt0.3Zn/SAPO-11; (5) Pt0.5Zn/SAPO-11; (6) Pt0.7Zn/SAPO-11.

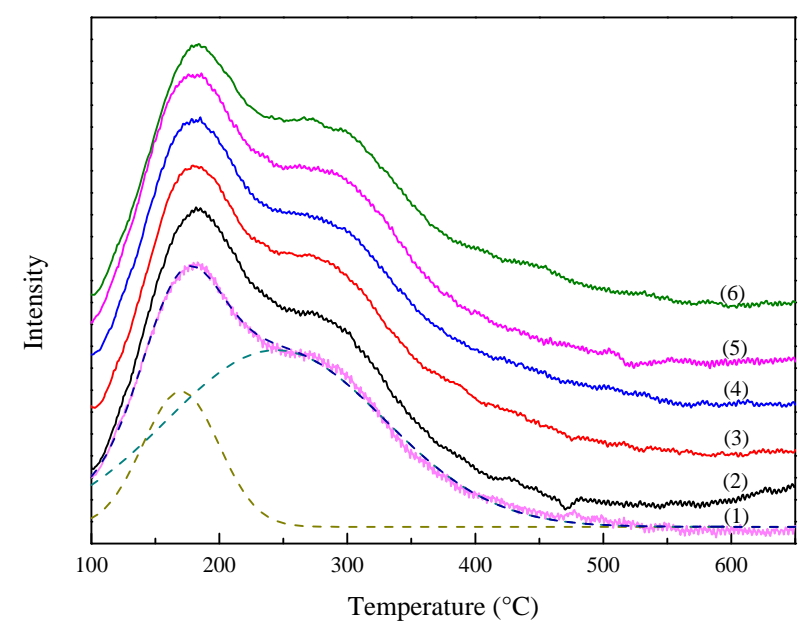

Fig. 4. $\mathrm{NH}_{3}$-TPD profiles of samples and fitted curves of SAPO-11. (1) SAPO-11; (2) Pt/SAPO-11; (3) Pt0.1Zn/SAPO-11; (4) Pt0.3Zn/SAPO-11; (5) Pt0.5Zn/SAPO-11; (6) Pt0.7Zn/SAPO-11. ical profile for deconvolution of SAPO-11 is shown) [35-37]. The numbers of acid sites were calculated and are shown in Table 1. The distribution of acid sites in the SAPO-11 support differed slightly from those in the catalysts. Pt/SAPO-11 had the lowest medium acidity and the highest weak acidity among all the samples. The differences among the acidic properties can be attributed to interactions between platinum clusters and acid sites [38]. The amounts of weak and medium acid sites increased and decreased, respectively, with increasing zinc loading. The total acidities of the Pt0.1Zn/SAPO-11 and Pt0.3Zn/SAPO- 11 catalysts were 258.3 and $256.4 \mu \mathrm{mol} / \mathrm{g}$, respectively. These are higher than the total acidity of SAPO-11, suggesting that the incorporated $\mathrm{Zn}^{2+}$ ions behaved as Lewis acid species and increased the acidities of the samples [31]. Pt0.7Zn/SAPO-11 showed the lowest total acidity, possibly because the high zinc loading led to coverage of some of the acid sites.

\section{3. $\mathrm{H}_{2}$-TPR and $\mathrm{H}_{2}$-TPD results}

The $\mathrm{H}_{2}$-TPR profiles of the samples are shown in Fig. 5. For the Pt/SAPO-11 catalyst, two platinum reduction peaks were observed in the ranges $100-200{ }^{\circ} \mathrm{C}$ and $400-500{ }^{\circ} \mathrm{C}$, which are assigned to platinum supported on the external surface and in the internal pores of the catalyst, respectively [36,39]. The intensity of the peak centered at about $450{ }^{\circ} \mathrm{C}$ in the profiles of the zinc-modified catalysts decreased with increasing zinc ad-

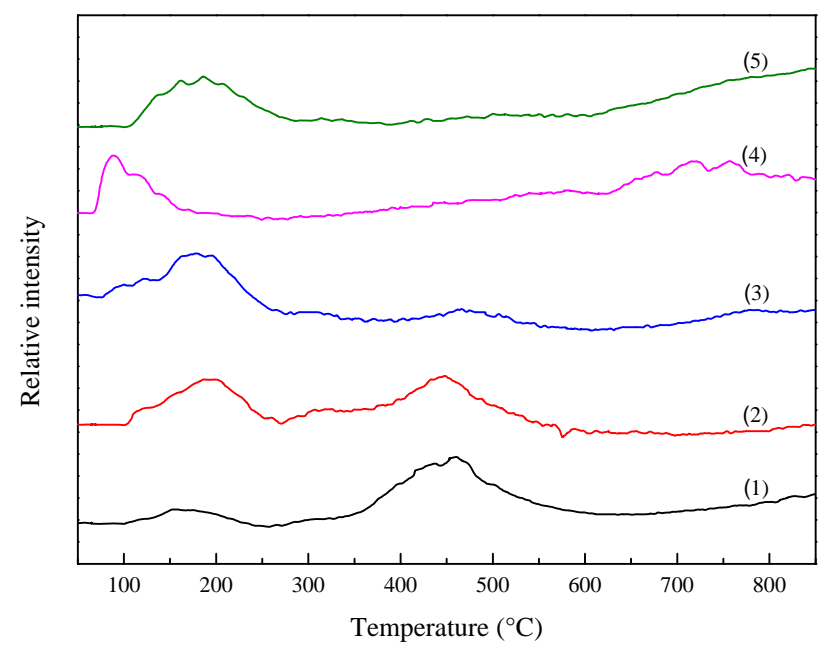

Fig. 5. $\mathrm{H}_{2}$-TPR profiles of catalysts. (1) Pt/SAPO-11; (2) Pt0.1Zn/ SAPO-11; (3) Pt0.3Zn/SAPO-11; (4) Pt0.5Zn/SAPO-11; (5) Pt0.7Zn/ SAPO-11. 


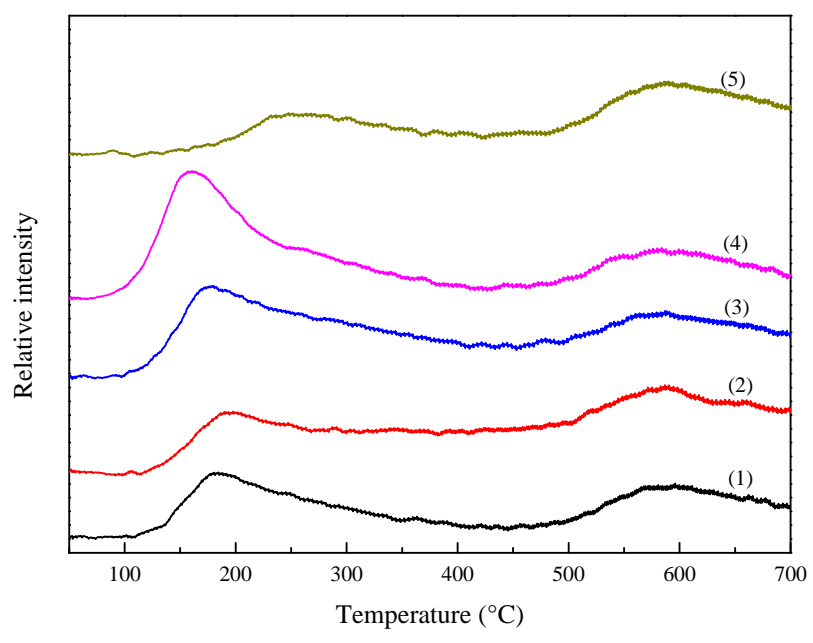

Fig. 6. $\mathrm{H}_{2}$-TPD profiles of catalysts. (1) Pt/SAPO-11; (2) Pt0.1Zn/ SAPO-11; (3) Pt0.3Zn/SAPO-11; (4) Pt0.5Zn/SAPO-11; (5) Pt0.7Zn/ SAP0-11.

dition. When the impregnation mixture is attached to the support, $\mathrm{Zn}^{2+}$ cations, which have a smaller atomic radius than platinum, are easily adsorbed on the hydroxyl groups in the internal pores of SAPO-11, and this hinders incorporation of platinum. Zinc can therefore act as a competitive adsorbent, resulting in platinum being mainly supported on the external surface of SAPO-11.

The $\mathrm{H}_{2}$-TPD profiles of the catalysts are shown in Fig. 6 . Two peaks were observed in the temperature range $150-600{ }^{\circ} \mathrm{C}$. The $\mathrm{H}_{2}$ desorption peak below $400{ }^{\circ} \mathrm{C}$ arises from $\mathrm{H}_{2}$ adsorbed on the platinum active sites and the other peak, above $400{ }^{\circ} \mathrm{C}$, is ascribed to spilt-over hydrogen [40,41]. The $\mathrm{H}_{2}$ desorption temperature decreased with increasing zinc loading, except in the case of the $0.7 \mathrm{Zn}$ catalyst. Among all the catalysts, the Pt0.5Zn/SAPO-11 catalyst showed the lowest desorption temperature, indicating that the interactions between active $\mathrm{H}$ and platinum are weak and hydrogen is easily activated. The ability of platinum to activate hydrogen is related to its dispersion. Table 1 shows the dispersion of platinum on the catalysts. The dispersion of platinum decreased in the order Pt0.3Zn/ SAPO-11 > Pt0.5Zn/SAP0-11 > Pt0.7Zn/SAPO- $11>$ Pt0.1Zn/ SAPO-11 > Pt/SAPO-11, suggesting that the introduction of zinc favors platinum dispersion. The Pt0.3Zn/SAPO-11 and Pt0.5Zn/SAPO-11 catalysts had larger numbers of exposed platinum atoms; this benefits hydrogen activation, and is in accordance with the $\mathrm{H}_{2}$-TPD results. The TEM images in Fig. 7 show the Pt particle size distributions for all the catalysts; the corresponding average particle sizes are shown in Table 1. The Pt particles in the PtxZn/SAPO-11 catalysts were smaller than those in the Pt/SAPO-11 catalyst, indicating that the Pt particle size was affected by the zinc loading. This result is in accordance with the platinum dispersions shown in Table 1 . The platinum dispersion of the Pt0.7Zn/SAPO-11 catalyst was higher than that of Pt/SAPO-11, but a clear $\mathrm{H}_{2}$ desorption peak was not observed. We identified the zinc species in the Pt0.7Zn/ SAPO- 11 catalyst using XPS. The $\mathrm{Zn} 2 p$ spectrum of the catalyst is shown in Fig. 8. A peak with a binding energy of $1022.4 \mathrm{eV}$ was observed, indicating the presence of $\mathrm{ZnO}$ species [42]. Xia et al. [43] reported that $\mathrm{ZnO}$ enhances $\mathrm{H}_{2}$ adsorption and promotes the formation of spilt-over hydrogen. Pt0.7Zn/SAPO-11, which had the largest amount of $\mathrm{ZnO}$, therefore gave an intense $\mathrm{H}_{2}$ desorption peak attributed to spilt-over hydrogen.

\subsection{Catalytic activities}

The hydroisomerization of $n$-octane was performed on Pt/SAPO-11 and the zinc-modified Pt/SAPO-11 catalysts. The $n$-octane conversions and isooctane selectivities as a function of reaction temperature are presented in Fig. 9. The conversion of $n$-octane increased with increasing reaction temperature. However, the selectivity for isooctane decreased with increasing reaction temperature, indicating that the hydrocracking

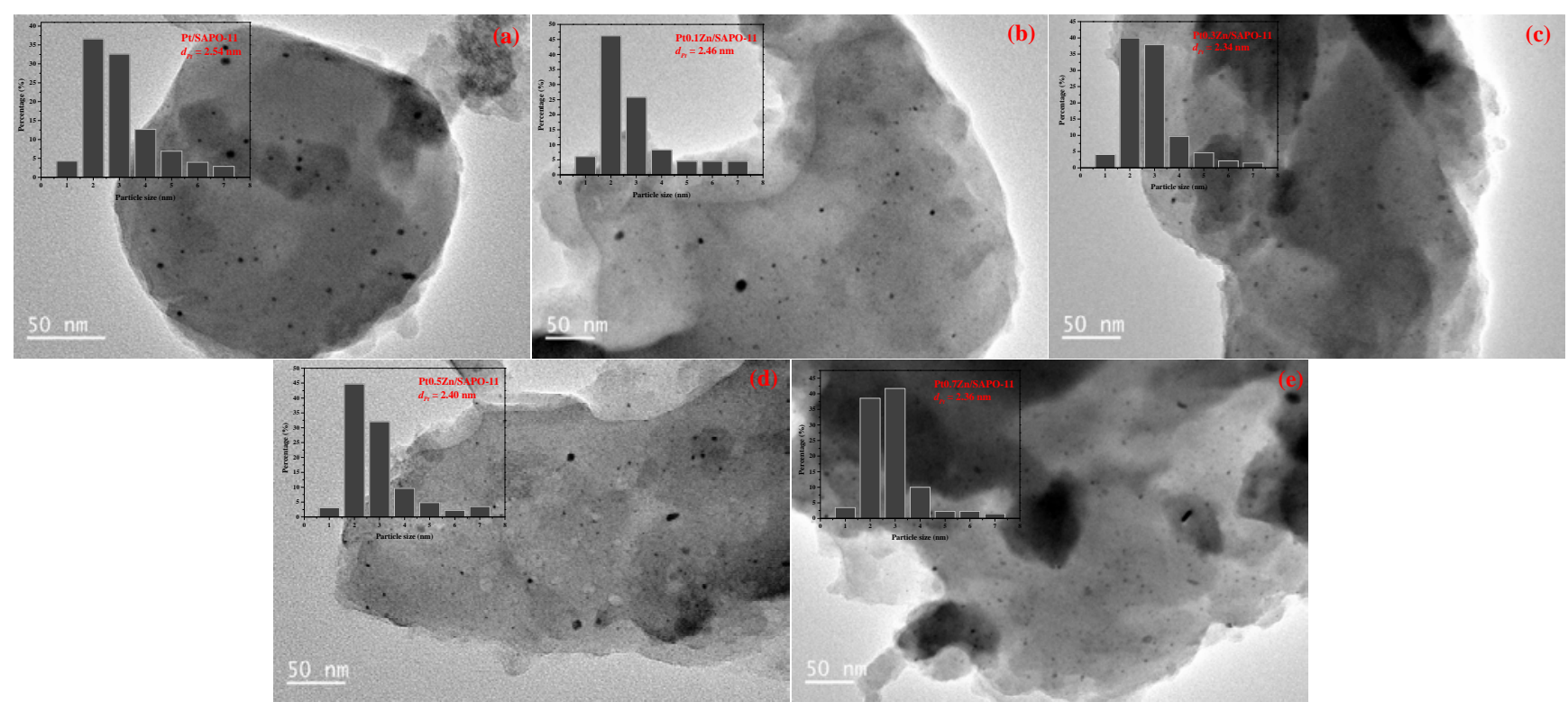

Fig. 7. TEM images and Pt particle size distributions of catalysts. (a) Pt/SAPO-11; (b) Pt0.1Zn/SAPO-11; (c) Pt0.3Zn/SAPO-11; (d) Pt0.5Zn/SAPO-11; (e) Pt0.7Zn/SAPO-11. 


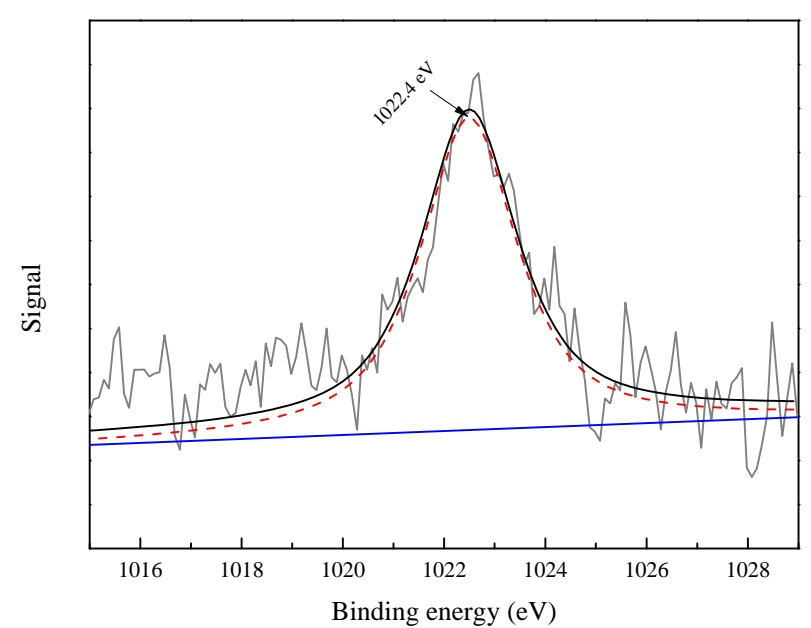

Fig. 8. Zn $2 p$ X-ray photoelectron spectrum of Pt0.7Zn/SAPO-11 catalyst.

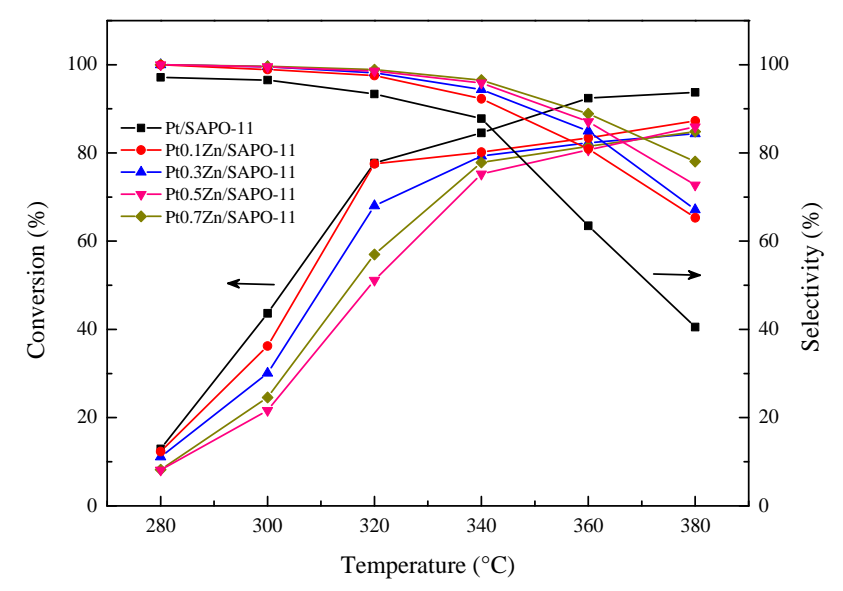

Fig. 9. Conversions of $n$-octane and selectivities to isooctane as a function of temperature on Pt/SAPO- 11 and PtxZn/SAPO- 11 catalysts at 2 $\mathrm{MPa}$, weight hourly space velocity $=1 \mathrm{~h}^{-1}, \mathrm{H}_{2} / n$-octane $(\mathrm{V} / \mathrm{V})=400$.

reaction rate increased at higher temperatures. The hydroisomerization activities of the tested catalysts decreased in the order Pt/SAPO-11 > Pt0.1Zn/SAPO-11 > Pt0.3Zn/SAPO-11 > Pt0.7Zn/SAPO-11 > Pt0.5Zn/SAPO-11. It is generally accepted that the activity of a bifunctional catalyst is related to the type and number of metal sites and acid sites. The characterization results suggest that the zinc-modified Pt/SAPO-11 catalysts have higher metal activities and similar acidic properties to those of Pt/SAPO-11. Their hydroisomerization activities should therefore be higher than that of Pt/SAPO-11, but the results suggest otherwise. The selectivities to DMHs and the total selectivity to isooctane as a function of $n$-octane conversion are shown in Fig. 10. When the $n$-octane conversion was below $80 \%$, the isooctane selectivity remained stable and the DMH selectivity increased with increasing conversion. However, the isooctane and DMH selectivities decreased at high $n$-octane conversions because hydrocracking was enhanced. When the $n$-octane conversion was greater than $80 \%$, we observed dimethylbenzenes (DMBs) in addition to cracking products. These DMBs are probably formed by subsequent reactions of isooctane. At conversions below 80\%, Pt/SAPO-11

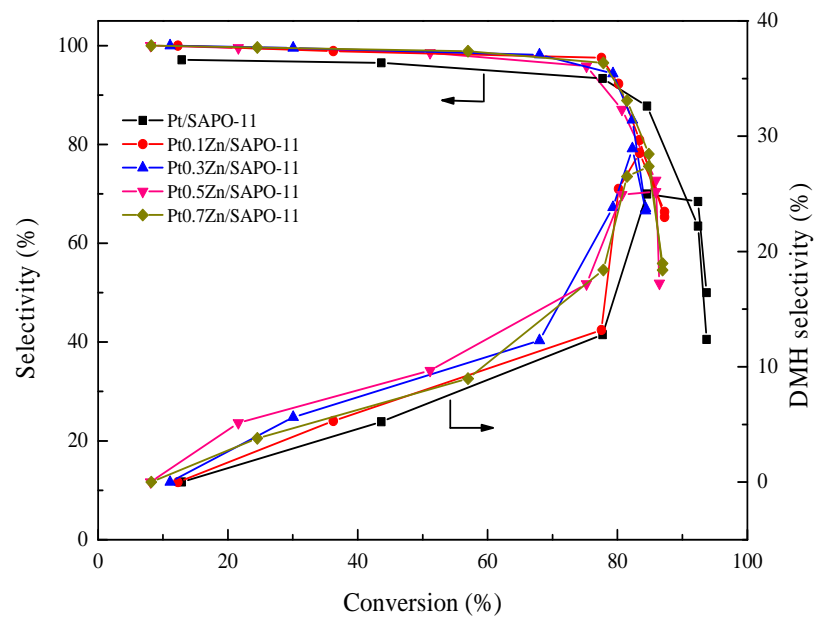

Fig. 10. Selectivities to isooctane and $\mathrm{DMH}$ as a function of conversion on Pt/SAPO-11 and PtxZn/SAPO-11 catalysts at $2 \mathrm{MPa}$, weight hourly space velocity $=1 \mathrm{~h}^{-1}, \mathrm{H}_{2} / n$-octane $(\mathrm{V} / \mathrm{V})=400$.

and the zinc-modified Pt/SAPO-11 catalysts gave good isomerization selectivities (>90\%). The DMH selectivities of the zinc-modified catalysts were higher than that of the Pt/SAPO-11 catalyst, especially at low conversions. In the reaction system, the critical molecular diameters of $n$-octane, monomethylheptane (MMH), and DMH are $0.49,0.56$, and 0.71 $\mathrm{nm}$, respectively $[9,44]$. Because of restriction by the pore diameter of SAPO-11 $(0.39 \mathrm{~nm} \times 0.63 \mathrm{~nm})[9,16]$, the $n$-octane molecule can be converted to MMH in the pore channels of SAPO-11. MMH is then converted to DMH at the pore mouths rather than in the microporous channels, according to the "pore mouth and key lock" concept [45]. The $\mathrm{H}_{2}$-TPR and $\mathrm{H}_{2}$-TPD results show that there were larger numbers of exposed platinum sites on the external surfaces of the zinc-modified Pt/SAPO-11 catalysts than on the external surface of the Pt/SAPO-11 catalyst. When MMH diffuses from the pore channels to the external surface of SAPO-11, further activation and conversion to DMH are therefore easier on the PtxZn/SAPO-11 catalysts. Among all the catalysts, Pt0.5Zn/SAPO-11 gave the highest selectivity to DMH. This is because of the larger amount of exposed platinum on the external surface of SAPO-11. However, Pt0.5Zn/SAPO-11 had the lowest isomerization activity under the same reaction conditions. This is because DMH, which has a large molecular diameter, suffers from diffusion limitation. When the zinc loading reached $0.7 \%$, the selectivity for DMH decreased. This could be because zinc acted as desorption-transfer sites, therefore a higher zinc loading promoted MMH desorption [30,31]. The Pt0.7Zn/SAPO-11 catalyst promoted formation of spilt-over hydrogen, and this also enhances MMH desorption [16]. A higher zinc loading therefore decreases the selectivity to DMH.

We further investigated the selectivities for DMH over Pt/SAPO-11 and Pt0.5Zn/SAPO-11 by assessing them at the same temperature, pressure, and $\mathrm{H}_{2} / n$-octane ratio, but different weight hourly space velocities. The results are shown in Fig. 11. The selectivity for DMH over both catalysts increased with increasing $n$-octane conversion. At the same conversion, the selectivity of Pt0.5Zn/SAPO-11 for DMH was higher than that of 


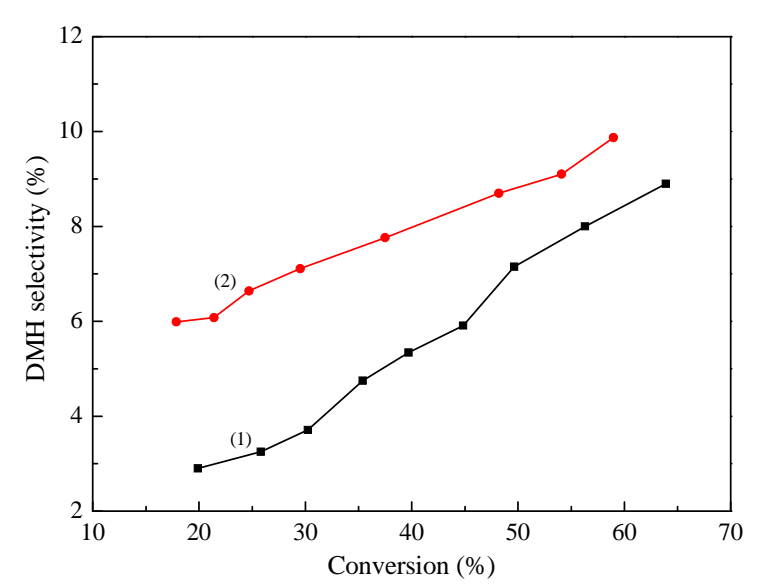

Fig. 11. Selectivities to DMH as a function of conversion on Pt/SAPO-11 (1) and Pt0.5Zn/SAPO- 11 (2) catalysts at $2 \mathrm{MPa}, 340{ }^{\circ} \mathrm{C}$, and $\mathrm{H}_{2} /$ $n$-octane $(\mathrm{V} / \mathrm{V})=400$.

Pt/SAPO-11. Below 25\% conversion, the selectivity to DMH over Pt0.5Zn/SAPO-11 was double that over Pt/SAPO-11, indicating that zinc addition improved the dibranched isomerization performance of the Pt/SAPO-11 catalyst. Table 2 shows the results for hydroisomerization of $n$-octane over the two catalysts at 30\% conversion. Pt/SAPO-11 and Pt0.5Zn/SAPO-11 showed similar selectivities to isooctane, i.e., nearly $100 \%$, but Pt0.5Zn/SAPO-11 gave a higher selectivity for DMH. For both catalysts, the selectivities for MMHs decreased in the order 2-methylheptane $\left(2-M_{7}\right)>3$-methylheptane $\left(3-M_{7}\right)>4$ methylheptane $\left(4-\mathrm{MC}_{7}\right)$. The major $\mathrm{DMH}$ products were $2,5-$ dimethylhexane (2,5-DMC6), 2,4-dimethylhexane (2,4-DMC6), and 2,3-dimethylhexane (2,3-DMC 6 ). A small amount of 3,4dimethylhexane $\left(3,4-\mathrm{DMC}_{6}\right)$ was obtained, but no 3,3-dimethylhexane $\left(3,3-\mathrm{DMC}_{6}\right)$ was detected at this conversion. These DMH products were considered to be formed by further skeleton isomerization of the formed $2-\mathrm{MC}_{7}$ [6]. No $\mathrm{DMB}$ species were detected at low $n$-octane conversions, but small amounts

\section{Table 2}

Results for $n$-octane isomerization over Pt/SAPO- 11 and Pt0.5Zn/ SAPO- 11 catalysts at $30 \%$ conversion.

\begin{tabular}{|c|c|c|}
\hline Catalyst $^{a}$ & Pt/SAP0-11 & Pt0.5Zn/SAPO-11 \\
\hline$\overline{S_{\mathrm{T}}(\%)}$ & 99.6 & 99.5 \\
\hline$S_{\text {MMH }}(\%)$ & 96.2 & 92.3 \\
\hline $2-\mathrm{MC}_{7}$ & 45.1 & 41.9 \\
\hline $3-\mathrm{MC}_{7}$ & 42.0 & 41.0 \\
\hline $4-\mathrm{MC}_{7}$ & 8.1 & 9.4 \\
\hline$S_{\text {DMH }}(\%)$ & 3.4 & 7.2 \\
\hline $2,3-\mathrm{DMC}_{6}$ & 0.6 & 1.4 \\
\hline 2,4-DMC 6 & 1.1 & 2.3 \\
\hline 2,5-DMC 6 & 1.4 & 2.9 \\
\hline $3,3-\mathrm{DMC}_{6}$ & 0 & 0 \\
\hline $3,4-\mathrm{DMC}_{6}$ & 0.3 & 0.6 \\
\hline$S_{\text {DMB }}(\%)$ & 0 & 0 \\
\hline$S_{\mathrm{C}}(\%)$ & 0.4 & 0.5 \\
\hline
\end{tabular}

of $p$-xylene and $o$-xylene were formed at conversions above $80 \%$.

\section{Conclusions}

Pt/SAPO-11 and zinc-modified Pt/SAPO-11 catalysts were prepared by incipient wetness impregnation. Zinc acted as a competitive adsorbate and therefore changed the location of platinum. The zinc-modified Pt/SAPO-11 showed higher dehydrogenation or hydrogenation activity because of improved platinum dispersion over SAPO-11. Among all the catalysts, Pt0.5Zn/SAPO-11 gave the highest selectivity for DMHs in the hydroisomerization of $n$-octane; this is because of the high dispersion of platinum and the location of platinum on the external surface. However, this catalyst also gave the lowest $n$-octane conversion under the same reaction conditions, possibly because DMHs have large molecular diameters and therefore suffer from molecular diffusion problems. When the zinc loading was increased to $0.7 \%$, zinc provided desorption-transfer sites and more spilt-over hydrogen was formed; this promoted $\mathrm{MMH}$ desorption and restrained further $\mathrm{MMH}$ skeleton isomerization. We suggest that zinc-modified $\mathrm{Pt} / \mathrm{SAPO}-11$ is a promising catalyst for improving the selectivity for DMHs in the hydroisomerization of $n$-octane. We will do further work to overcome diffusion limitations and improve the hydroisomerization activity.

\section{References}

[1] D. N. Gerasimov, V. V. Fadeev, A. N. Loginova, S. V. Lysenko, Catal. Ind., 2015, 7, 128-154.

[2] A. Chica, A. Corma, J. Catal., 1999, 187, 167-176.

[3] H. Deldari, Appl. Catal. A, 2005, 293, 1-10.

[4] A. Soualah, J. L. Lemberton, L. Pinard, M. Chater, P. Magnoux, K. Moljord, Appl. Catal. A, 2008, 336, 23-28.

[5] Y. Ono, Catal. Today, 2003, 81, 3-16.

[6] Y. Fan, H. Xiao, G. Shi, H. Y. Liu, X. J. Bao, J. Catal., 2012, 285, 251-259.

[7] L. Guo, X. J. Bao, Y. Fan, G. Shi, H. Y. Liu, D. J. Bai, J. Catal., 2012, 294, 161-170.

[8] L. Guo, Y. Fan, X. J. Bao, G. Shi, H. Y. Liu, J. Catal., 2013, 301, 162-173.

[9] P. Mériaudeau, V. A. Tuan, V. T. Nghiem, S. Y. Lai, L. N. Hung, C. Naccache, J. Catal., 1997, 169, 55-66.

[10] A. Patrigeon, E. Benazzi, Ch. Travers, J. Y. Bernhard, Catal. Today, 2001, 65, 149-155.

[11] J. Walendziewski, B. Pniak, Appl. Catal. A, 2003, 250, 39-47.

[12] E. Lee, S. Yun, Y. K. Park, S. Y. Jeong, J. Han, J. K. Jeon, J. Ind. Eng. Chem., 2014, 20, 775-780.

[13] C. H. Geng, F. Zhang, Z. X. Gao, L. F. Zhao, J. L. Zhou, Catal. Today, 2004, 93-95, 485-491.

[14] R. Yadav, A. Sakthivel, Appl. Catal. A, 2014, 481, 143-160.

[15] J. M. Campelo, F. Lafont, J. M. Marinas, Appl. Catal. A, 1998, 170, 139-144.

[16] M. Höchtl, A. Jentys, H. Vinek, J. Catal., 2000, 190, 419-432.

[17] M. Höchtl, A. Jentys, H. Vinek, Catal. Today, 2001, 65, 171-177.

[18] M. D. Romero, J. A. Calles, A. Rodríguez, J. C. Cabanelas, Ind. Eng. Chem. Res., 1998, 37, 3846-3852.

[19] C. X. Wang, Q. H. Liu, J. Song, W. Li, P. Li, R. S. Xu, H. J. Ma, Z. J. Tian, 


\section{Graphical Abstract}

Chin. J. Catal., 2017, 38: 509-517 doi: 10.1016/S1872-2067(17)62755-4

Zinc-modified Pt/SAPO-11 for improving the isomerization selectivity to dibranched alkanes

Zhichao Yang, Yunqi Liu*, Jinchong Zhao, Jianxia Gou, Kaian Sun, Chenguang Liu

China University of Petroleum (East China)

Zinc-modified Pt/SAPO-11 catalysts were prepared, characterized, and assessed in the hydroisomerization of $n$-octane. The dimethylhexane selectivities of the modified catalysts were higher than that of unmodified Pt/SAPO-11.

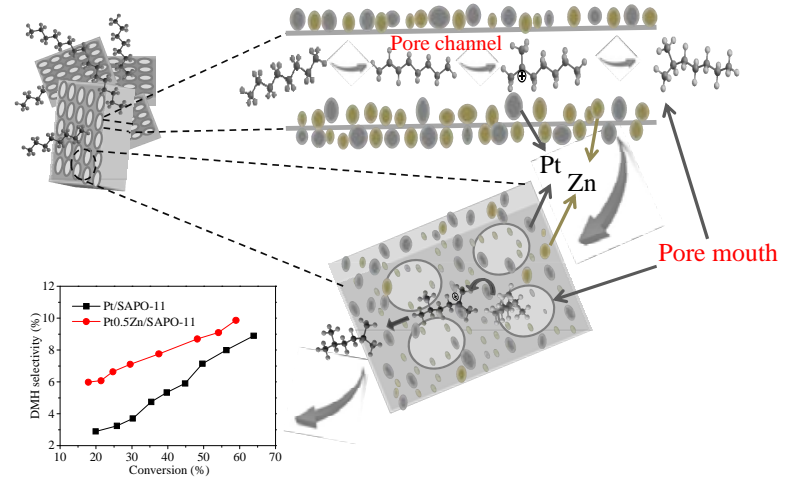

Catal., 2007, 28, 857-864.

[34] R. Yadav, A. K. Singh, A. Sakthivel, Chem. Lett., 2013, 42, 1160-1162.

[35] S. F. Gong, N. Chen, S. Nakayama, E. W. Qian, J. Mol. Catal. A, 2013 370, 14-21.

[36] X. Cui, Y. X. Liu, X. M. Liu, Catal. Lett., 2015, 145, 1464-1473.

[37] S. F. Gong, A. Shinozaki, E. W. Qian, Ind. Eng. Chem. Res., 2012, 51, 13953-13960.

[38] P. Liu, J. Ren, Y. H. Sun, Microporous Mesoporous Mater., 2008, 114, 365-372.

[39] X. M. Yang, H. J. Ma, Z. S. Xu, Y. P. Xu, Z. J. Tian, L. W. Lin, Catal. Commun., 2007, 8, 1232-1238.

[40] J. T. Miller, B. L. Meyers, F. S. Modica, G. S. Lane, M. Vaarkamp, D. C. Koningsberger, J. Catal., 1993, 143, 395-408.

[41] R. Prins, Chem. Rev., 2012, 112, 2714-2738.

[42] M. N. Islam, T. B. Ghosh, K. L. Chopra, H. N. Acharya, Thin Solid Films, 1996, 280, 20-25.

[43] S. X. Xia, R. F. Nie, X. Y. Lu, L. N. Wang, P. Chen, Z. Y. Hou, J. Catal., 2012, 296, 1-11.

[44] V. M. Akhmedov, S. H. Al-Khowaiter, Catal. Rev. Sci. Eng., 2007, 49, 33-139.

[45] M. C. Claude, J. A. Martens, J. Catal., 2000, 190, 39-48.

[33] S. Z. Zhang, S. L. Chen, P. Dong, Z. Y. Ji, J. Y. Zhao, K. Q. Xu, Chin. J.

\section{Zn改性的Pt/SAPO-11催化剂及其提高二甲基烷烃选择性}

杨志超, 柳云骐 ${ }^{*}$, 赵晋肿, 苟建霞, 孙凯安, 刘晨光 中国石油大学(华东)重质油国家重点实验室, CNPC催化重点实验室, 山东青岛266580

摘要: 随着环保法规的日益苛刻, 世界各国对发动机燃料指标的要求也越来越严格, 汽油组分中的烯烃含量逐渐被限制. 作为提高汽油辛烷值的有效手段, 正构烷烃的临氢异构化越来越引起人们的重视. 烷烃碳数相同时, 具有多支链的异构体 往往具有更高的辛烷值. 因此, 在正构烷烃临氢异构化过程中, 提高多支链异构体的选择性具有重要意义. Pt/SAPO-11作 为双功能催化剂具有适宜的孔结构、温和的酸性和适度的加氢脱氢活性, 在烷烃临氢异构化反应中表现出色, 得到了广泛 研究. 已有文献报道中, 通过添加第二金属改性可以调节双功能催化剂的物理化学性质, 进而影响其催化活性和产物选择 性. 为了提高异构产物选择性, 特别是多支链异构产物的选择性, 本文研究了Zn改性的Pt/SAPO-11催化剂在正辛烷临氢异 构化中的反应性能, 与未改性的Pt/SAPO-11催化剂相比, Zn改性的Pt/SAPO-11催化剂表现出更高的二甲基烷烃选择性.

通过动态合成方法合成SAPO-11分子篎, 进而制备Zn改性的Pt/SAPO-11催化剂. XRD表征表明, Pt和Zn的引入基本没 有引起SAPO-11特征峰改变, 并且未发现 $\mathrm{Pt}$ 和Zn氧化物的特征峰, 说明金属组分得到很好的分散. 氮气吸附-脱附实验表明, 随着Zn添加量的增加, 载体的比表面积和孔体积略有减少. $\mathrm{NH}_{3}$-TPD和吡啶红外光谱用于表征 $\mathrm{Zn}$ 的加入对催化剂酸性的 影响, 结果表明, 少量Zn的添加可以增加酸量, 这是由于Zn的引入可以产生 L酸性位; 而随着 $\mathrm{Zn}$ 的增加, 总酸量减少, 这是由 
于过多的 $\mathrm{Zn}$ 覆盖了载体的酸性位. $\mathrm{H}_{2}-\mathrm{TPR}$ 和 $\mathrm{H}_{2}-\mathrm{TPD}$ 表征发现, $\mathrm{Zn}$ 的引入使得Pt在高温处的还原峰减小, 说明 $\mathrm{Zn}$ 改变了 $\mathrm{Pt}$ 在 载体上的位置, 使其主要负载在分子笁外表面. 由于 $\mathrm{Zn}^{2+}$ 是阳离子并具有较小的离子半径, 它可以作为竞争吸附剂, 首先进 入分子笁孔道从而抑制了 $\mathrm{Pt}$ 进入分子篮孔道. $\mathrm{H}_{2}$ - TPD表明, $\mathrm{Zn}$ 的引入使得 $\mathrm{H}_{2}$ 的脱附温度逐渐降低, 这与 $\mathrm{Zn}$ 增加了 Pt的分散 度有关; 但是当 $\mathrm{Zn}$ 的添加量达到 $0.7 \%$ 时, $\mathrm{H}_{2}$ 的脱附温度升高, 同时溢流氢增加.

以正辛烷为模型化合物, 在固定床高压微型反应装置中对一系列催化剂进行了评价, 考察了Zn改性的Pt/SAPO-11催化 剂和未改性的Pt/SAPO-11催化剂的催化性能. 与未改性催化剂相比, Zn改性的催化剂在相同转化率条件下, 异辛烷的选择 性基本相同, 但是二甲基己烷的选择性明显提高. 当Zn的添加量为 $0.5 \%$ 时, 二甲基己烷选择性达到最大值, 继续提高Zn的 添加量, 其选择性下降. 值得注意的是, 在相同反应条件下, 未改性的催化剂具有更高的正辛烷转化率. 我们分析认为, 由 于Zn的添加促进了二甲基己烷的产生, 而其具有较大的分子尺寸, 在反应中存在扩散问题, 影响了改性催化剂的异构化活 性. 本文工作表明, 适宜的Zn添加量有利于提高二甲基烷烃的选择性, 对于提高汽油辛烷值具有重要意义.

关键词: Pt/SAPO-11催化剂; 锌; 正辛烷; 临氢异构化; 二甲基烷烃

收稿日期: 2016-10-26. 接受日期: 2016-11-21. 出版日期: 2017-03-05.

*通讯联系人. 电话: (0532)86981861; 传真: (0532)86981787; 电子信箱: liuyq@upc.edu.cn

基金来源: 国家自然科学基金(21676300).

本文的英文电子版由Elsevier出版社在ScienceDirect上出版(http://www.sciencedirect.com/science/journal/18722067). 